\title{
Comparative Study of Gold Concentration by Elutriation from Different Precious Metal Bearing Ores
}

\author{
Martín A. Encinas-Romero*, Guillermo Tiburcio-Munive, Jesús L. Valenzuela-García \\ Departamento de Ingeniería Química y Metalurgia, Universidad de Sonora, Hermosillo, México \\ Email: *maencinas@iq.uson.mx \\ Received February 11, 2013; revised May 28, 2013; accepted June 10, 2013
}

Copyright (C) 2013 Martín A. Encinas-Romero et al. This is an open access article distributed under the Creative Commons Attribution License, which permits unrestricted use, distribution, and reproduction in any medium, provided the original work is properly cited.

\begin{abstract}
Conventional methods for precious metals gravimetric concentration involve equipment such as shaking tables, centrifuging concentrators, jigs, trommels, or a combination of those. A less commonly used technique is elutriation, which represents an efficient, safe and low-cost method of separation. The goal of the present investigation was to make a comparative study of gold concentration by elutriation from different precious metal bearing ores: an oxide ore, a mineral consisting of a sulfide matrix, a mineral in which the precious metals are free and disseminated and a slimy and clayey black sand material. The best recoveries of precious metals by elutriation were attained for the free disseminated ore and for the black sands, obtaining gold recoveries of $70 \%$ and $96 \%$ respectively, with appreciable ratios of concentration as well.
\end{abstract}

Keywords: Elutriation; Precious Metals; Oxides, Sulfides; Free Gold; Black Sands

\section{Introduction}

Elutriation is a particulate separation process in which an upward fluid stream generally air or water is used. The classification is made through a series of tubular or conical vessels of increasing size, so that the flow rate decreases successively from one of vessel to the next.

Generally, an elutriator consists of one or more "sorting columns" in which the fluid flows upwards at a constant velocity. Feed particles introduced into the sorting column will be separated into two fractions, according to their terminal velocities calculated from Stoke's Law. Particles with a terminal velocity smaller than the fluid mean flow rate will overflow, whereas those with a larger velocity than the mean flow rate will sink toward the underflow. Elutriation is carried out until either no visual signs of a further separation are observed, or there is no change in the weight proportions of the products [1].

Elutriation with air is faster than elutriation with a liquid. It also tends to be more efficient due to a lower air resistance to the particles fall, and to a less tendency for agglomeration of particles [1,2].

Elutriation with liquids is a process of separation or sub-separation of particulate of different sizes within a

"Corresponding author. fluid stream, such as water. If the specific gravity of the feed material is uniform, the resulting grades of the product streams can be significantly uniform even for very narrow size ranges. On the other hand, a considerable size variation of the product streams occurs when there are large differences in specific gravity or particle size of the feed even for narrow size ranges $[3,4]$.

The main advantage of elutriation is the absence of moving parts. It represents an economic alternative as a method for precious metal concentration. The main disadvantage of elutriation is related to the velocity profile, originating across the fluid stream due to the resistance imposed by the vessel walls. Thus, the particles are exposed to a fluid velocity field that varies with the radial position in the vessel. In fact, these particles are carried toward the region of high-speed flow due to the pressure differences on their surfaces. Consequently, the highspeed fluid captures these particles, reducing thereafter the efficiency of the elutriator [5].

There are no recent reports on the use of the elutriation with liquids as applied to upgrade precious metal minerals. Therefore, as a part of a general project on the use of the non-conventional methods for precious metal gravity concentration, the following study was undertaken. The goal of this study is to compare the precious metals concentration by elutriation as applied to different ores. Gold 
recoveries and concentration ratios for those materials were measured and used as comparison parameters.

\section{Materials and Methods}

\subsection{Feed Materials}

The study involved the treatment of four different types of feed materials from regional mining deposits:

1) Oxide ore

2) Sulfide ore

3) Free gold ore, and

4) Black sands

The as-received materials were first crushed in a $170 \times$ 135 jaw crusher. Afterwards, they were secondary crushed in a $222 \mathrm{~mm}$ cone crusher. Then, they were pulverized in a $222 \mathrm{~mm}$ ring pulverizer. Finally, the materials were wet-screened and dried to prepare close-sized feeding for the elutriation tests. A representative simple for every size range was taken for gold analysis and the results are presented in Table $\mathbf{1}$.

With the exception of black sands, chemical and X-ray analysis were made for bulk samples of the different ores. Also, specific gravities for every mineral studied were determined by a picnometer. Table 2 presents the results. The main mineral species present in the oxide ore are quartz and Fe-bearing minerals (hematite, limonite and jarosite). For the sulfide ore, pyrite is the main component, whereas silicates (quartz, orthoclase, albite and muscovite) are the most abundant species in the free-gold ore.

\subsection{Elutriation Equipment}

The elutriation equipment consisted of two sorting columns of PVC as shown in Figure 1. Both columns have diameters of $50.8 \mathrm{~mm}(2$ ") and the lengths for the elutria- tion section are $1054.1 \mathrm{~mm}$ (41.5”) and $482.6 \mathrm{~mm}$ (19"), respectively. Details of equipment facilities are given elsewhere [6].

A typical run involved the following steps. Firstly, the elutriator is assembled as shown in Figure 1 and the concentrate 1 , concentrate 2 and tailings containers are positioned tightly in place. Afterwards, the water feed valve is opened to fill up completely the first column and partially the second one. The sample was mixed with water aiming at preparing a slurry containing $30 \%$ of solids (weight basis). This pulp is put into the feed tank and is kept continuously stirred to maintain the solids in suspension.

A test started by opening the pulp feed valve and regulating its flow rate within the range 6 to $13 \mathrm{l} / \mathrm{h}$, and the feed water flow rate, within the range 30 to $121 \mathrm{l} / \mathrm{h}$. The precise velocity ratio for every particle size is adjusted when a clear and constant separation of the two fractions is obtained. Typically, when the particle size decreases much slower feed and washing flow rates are used than with coarser particles. The experiment was stopped until no visible signs of particle separation were observed. The products: concentrates 1 and 2 and tailings were dried at $100^{\circ} \mathrm{C}$ and analyzed by fire assay for its gold contents.

\section{Results and Discussion}

\subsection{Oxide Ore}

Figures 2 and $\mathbf{3}$ show the gold distribution and ratio of concentration for concentrates 1 and 2, respectively, for the oxide ore. For small particles sized the greatest recoveries are found in the concentrate $2(>90 \%)$. However, as Figure 3 shows, the concentration ratios in this fraction have an average value of $1: 1$, which means that most of the feed ore stays in the concentrate 2 without any appreciable upgrading. On the other hand, as the particle

Table 1. Gold head essay for different particle size of the minerals tested.

\begin{tabular}{|c|c|c|c|c|c|}
\hline \multicolumn{2}{|c|}{ Size Distribution } & \multicolumn{4}{|c|}{ Gold Head Essay (g/ton) } \\
\hline Mesh Size & $\begin{array}{c}\text { Average Particle } \\
\text { Size }(\mu \mathrm{m})\end{array}$ & Oxide Mineral & Sulfide Mineral & Free Gold Mineral & Black Sand \\
\hline$-40 ;+60$ & 302.5 & na & na & na & 0.72 \\
\hline$-60 ;+100$ & 200 & na & na & na & 0.39 \\
\hline$-80 ;+100$ & 165 & 0.3 & 7.07 & 38.2 & na \\
\hline$-100 ;+150$ & 128 & 0.26 & 66.75 & 36.6 & 0.65 \\
\hline$-150 ;+200$ & 90.5 & 0.20 & 74.94 & 26.65 & na \\
\hline$-200 ;+270$ & 64 & 0.33 & 102.7 & 23.12 & na \\
\hline $0.270 ;+325$ & 49 & 0.33 & 74.98 & 15.73 & na \\
\hline-325 & 45 & 0.46 & 106.6 & na & 0.40 \\
\hline
\end{tabular}

na: not applicable. 
Table 2. Chemical composition and X-ray difraction analysis for the different minerals tested.

\begin{tabular}{|c|c|c|c|c|}
\hline \multirow[t]{2}{*}{ Species } & \multicolumn{4}{|c|}{ Composition (\%w/w) } \\
\hline & Oxide Mineral & Sulfide Mineral & Fee Gold Mineral & Black Sand \\
\hline $\mathrm{SiO}_{2}$ & $>30$ & $>30$ & $>30$ & 8.4 \\
\hline $\mathrm{Fe}$ & 14.2 & 19.8 & 3.92 & 58.83 \\
\hline $\mathrm{Cu}$ & 0.031 & 0.21 & 0.30 & \\
\hline $\mathrm{Pb}$ & & 1.96 & 0.020 & \\
\hline $\mathrm{Zn}$ & 0.20 & 0.26 & 0.020 & \\
\hline $\mathrm{Cr}_{2} \mathrm{O}_{3}$ & & & & 0.04 \\
\hline $\mathrm{ZrO}_{2}$ & & & & 0.054 \\
\hline $\mathrm{Fe}_{2} \mathrm{O}_{3}$ (hematite) & $<5$ & $<5$ & $<5$ & \\
\hline $\mathrm{Fe}_{2} \mathrm{O}_{3} \mathrm{Fe}_{2} \mathrm{O}_{3} \cdot \mathrm{H}_{2} \mathrm{O}$ (limonite) & $<5$ & $<5$ & & \\
\hline $\mathrm{KFe}\left(\mathrm{SO}_{4}\right)_{2}(\mathrm{OH})_{6}$ (jarosite) & $<5$ & $<5$ & & \\
\hline$(\mathrm{NaK}) \mathrm{Al}_{3}\left(\mathrm{SO}_{4}\right)_{2}(\mathrm{OH})_{6}$ (natrualunite) & $<5$ & & & \\
\hline $\mathrm{PbFe}_{6}\left(\mathrm{SO}_{4}\right)_{4}(\mathrm{OH})_{12}$ (plumbojarosite) & $<5$ & & & \\
\hline $\mathrm{FeS}_{2}$ (pyrite) & $<5$ & $<5$ & $10-15$ & \\
\hline $\mathrm{KAlSi}_{2} \mathrm{O}_{8}$ (orthoclase) & $<5$ & $<5$ & $10-15$ & \\
\hline $\mathrm{NaAlSiO}_{3}$ (albite) & $<5$ & & & \\
\hline $\mathrm{PbS}$ (galena) & $<5$ & & & \\
\hline $\mathrm{KAl}_{2} \mathrm{Si}_{2} \mathrm{AlO}_{10}(\mathrm{OH})_{2}$ (muscovite) & & $<5$ & $5-10$ & \\
\hline K-Na-Mg-Fe-Al-Si-O- $\mathrm{H}_{2} \mathrm{O}$ (iccite) & & $<5$ & & \\
\hline $\mathrm{Al}_{2} \mathrm{SiO}_{5}(\mathrm{OH})_{4}($ kaolinite $)$ & & $<5$ & & \\
\hline $\mathrm{FeO}(\mathrm{OH})$ (goethite) & & $<5$ & & \\
\hline $\mathrm{PbCO}_{3}$ (cerusite) & & $<5$ & & \\
\hline $\mathrm{Ca}-\mathrm{Na}-\mathrm{Mg}$-Fe-Al-Si-O-OH- $\mathrm{H}_{2} \mathrm{O}$ (montmorillonite) & 0.20 & 74.49 & 39.43 & 0.36 \\
\hline $\mathrm{Au}-80$ mesh (g/ton) 0.2 & & & & \\
\hline Bulk Specific Gravity $\left(\mathrm{g} / \mathrm{cm}^{3}\right)$ & 3.62 & 3.56 & 3.64 & 5.34 \\
\hline
\end{tabular}

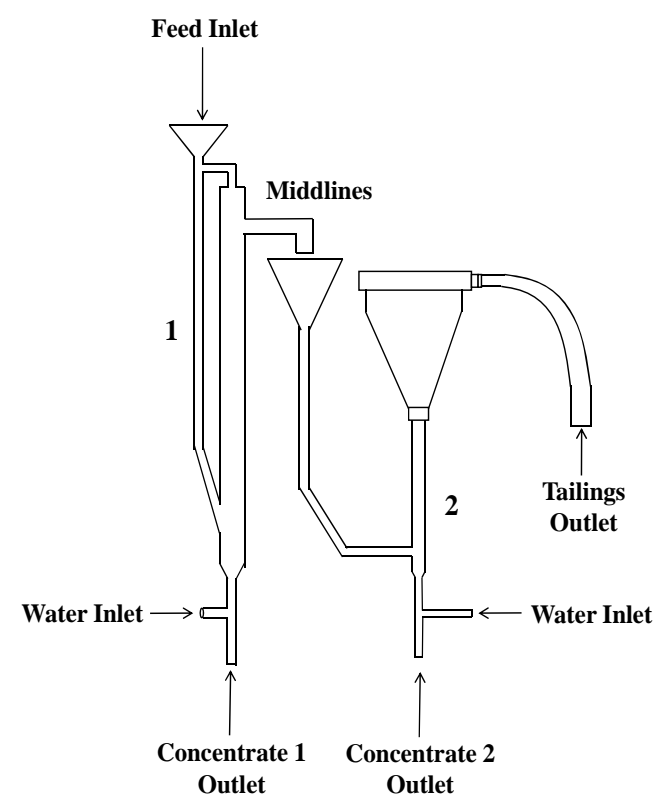

Figure 1. Schematic diagram of experimental elutriator. Numbers 1 and 2 refer to first and second elutriators. size increases recovery in the concentrate 1 increases. Gold recoveries of $74 \%$ were obtained for the particle sizes of $165 \mu \mathrm{m}(-80+100$ mesh), and gold concentration ratios of the order of 5.5:1. As an important $\% \mathrm{w} / \mathrm{w}$ in this ore corresponds to iron oxides, others researchers had reported that the smaller iron oxides particles are not easily elutriated from fluidized beds of mixed size particles [7]. These results are consistent with the results of present study.

\subsection{Sulfide Ore}

Regarding the sulfide ore, Figures $\mathbf{4}$ and $\mathbf{5}$ indicate a poor gold recovery for both concentrates $(<8 \%)$. For coarser sizes a slight increase in recovery was observed for concentrate 1 whereas for concentrate 2 the increase is more significant (from $10 \%$ to $60 \%$ ), similar to the behavior observed with the oxide ore. However, the increase in gold distribution is accompanied by a drastic decrease in the ratio of concentration indicating that most of the gold values are lost in the tailings. 


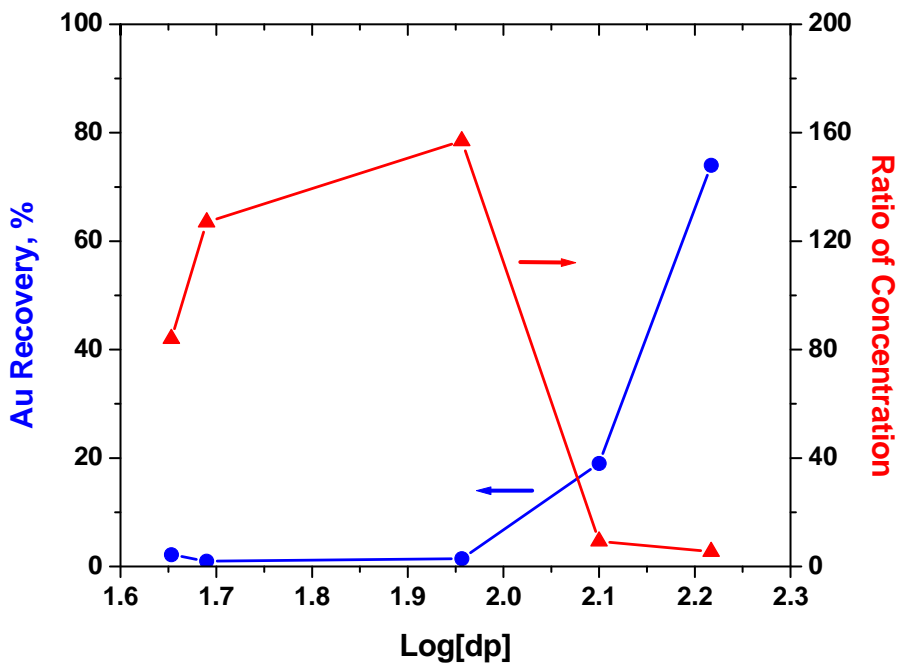

Figure 2. Gold recovery and ratio of concentration, as a function of a particle size, for concentrate 1 of oxide mineral.

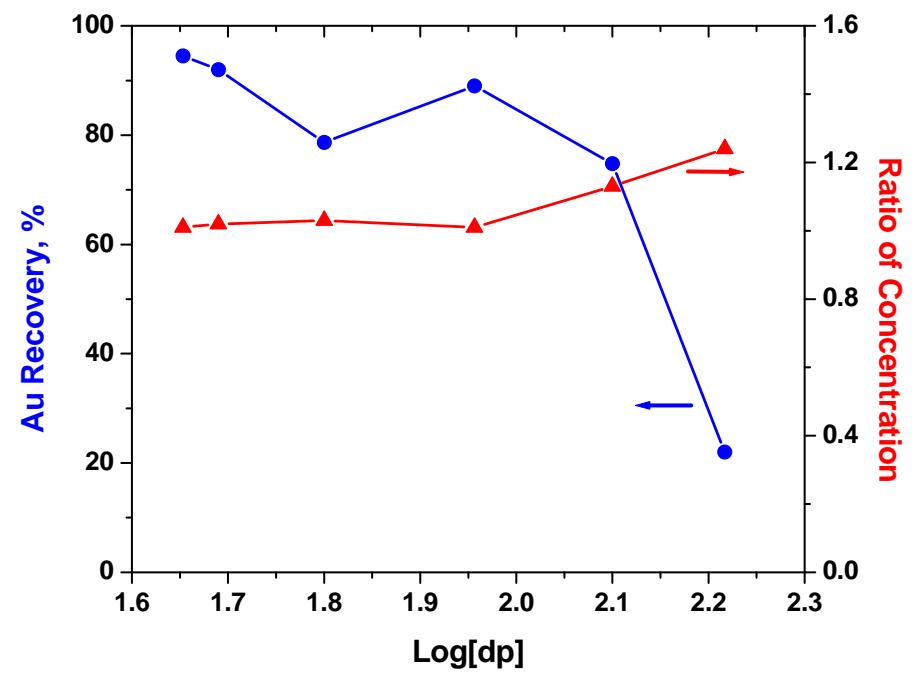

Figure 3. Gold recovery and ratio of concentration, as a function of a particle size, for concentrate 2 of oxide mineral.

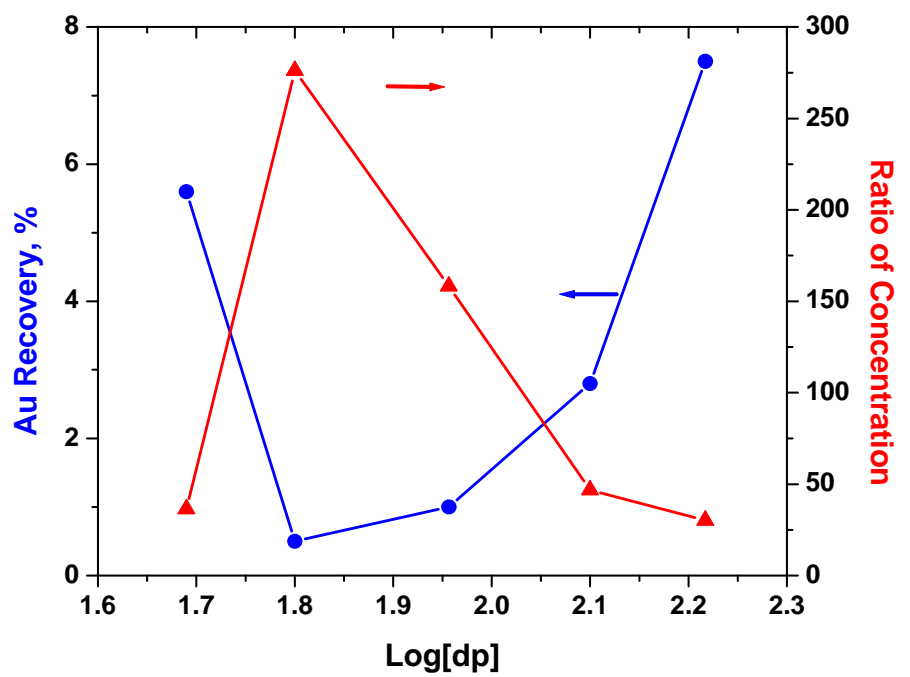

Figure 4. Gold recovery and ratio of concentration, as a function of a particle size, for concentrate 1 of sulfide mineral. 


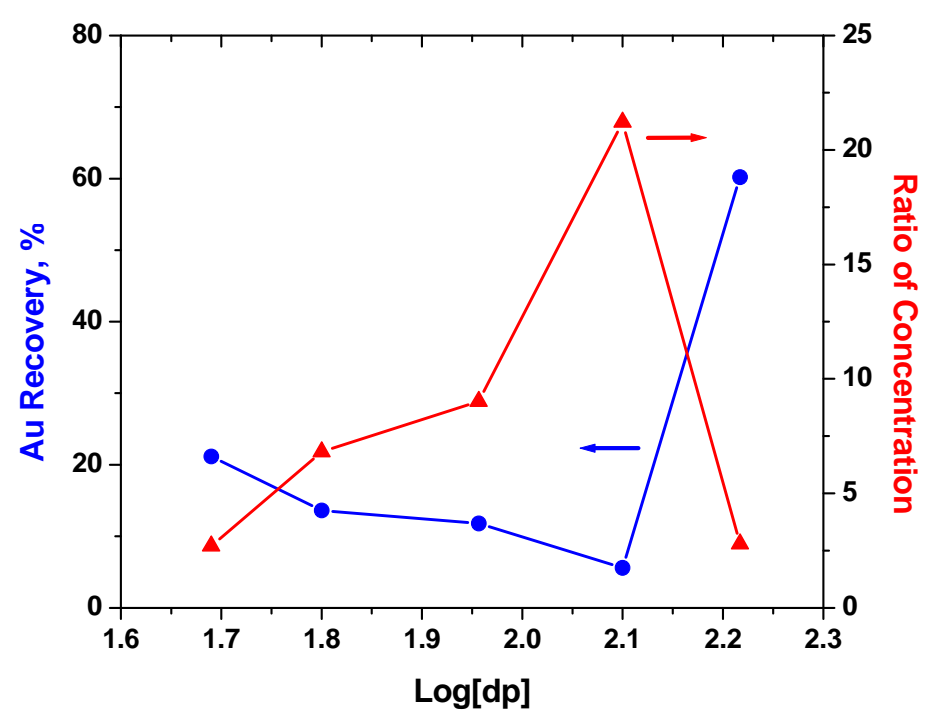

Figure 5. Gold recovery and ratio of concentration, as a function of a particle size, for concentrate 2 of sulfide mineral.

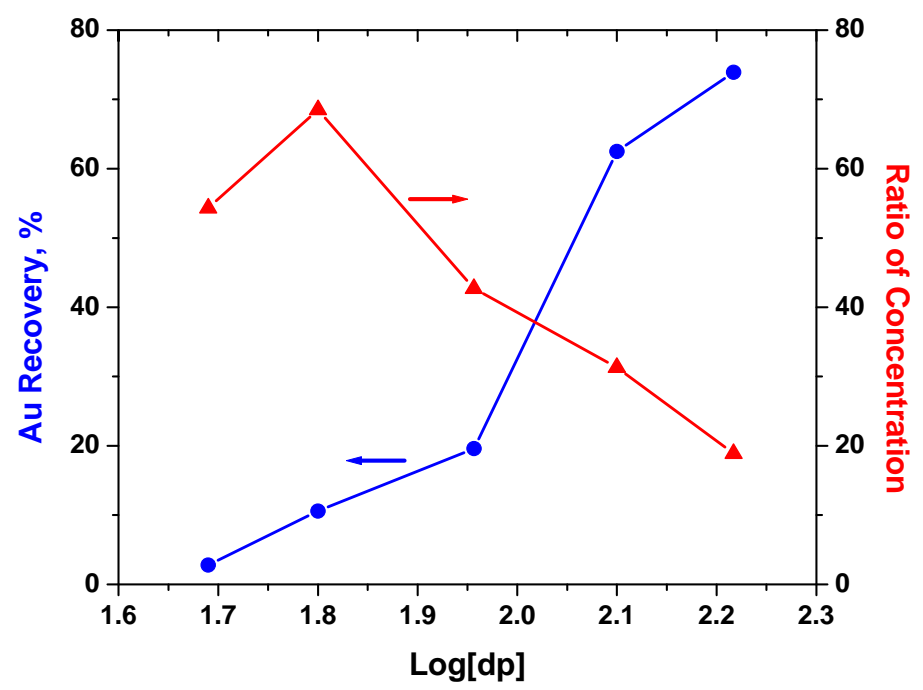

Figure 6. Gold recovery and ratio of concentration, as a function of a particle size, for concentrate 1 of free gold mineral.

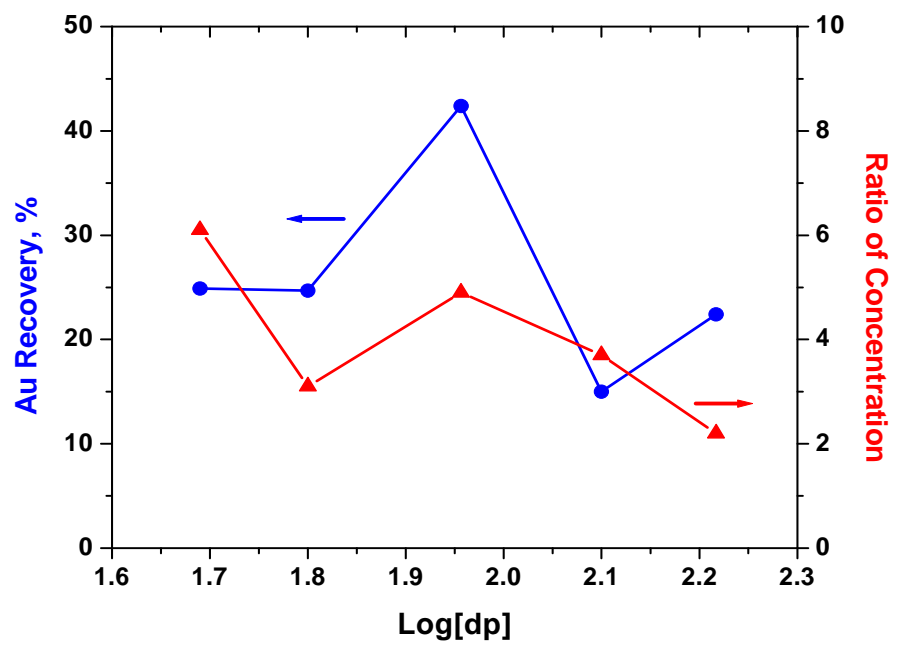

Figure 7. Gold recovery and ratio of concentration, as a function of a particle size, for concentrate 2 of free gold mineral. 


\subsection{Free Gold}

For the free gold ore, Figures 6 and $\mathbf{7}$ depict the variation of gold recovery and ratios of concentration against particle size for concentrates 1 and 2, respectively. Compared to previous materials, here a significant difference is observed. For coarser sizes concentrate 1 has gold contents above $70 \%$ and reasonable ratios of concentration average 70:1. For smaller particle sized, the greatest proportion of gold is present in concentrate 2, with appreciable ratios of concentration as well. This kind of materials showed a better response to elutriation as compared to the other minerals.

\subsection{Black Sands}

In the case of black sands, a great susceptibility to this treatment was observed. Figures 8 and $\mathbf{9}$ indicate that for almost the whole particle size range studied, excellent recoveries were obtained, e.g. $96 \%$ gold recovery in concentrate 1 fraction with adequate concentration ratios, as Figure 8 shows. For coarser particle sizes, most of the gold reported in concentrate 2 as shown in Figure 9. Because this kind of ores contain relatively pure, wellsorted heavy mineral concentrates, they are separated from larger, less dense particles limiting the settling of larger, less dense particles, but also allows smaller, denser particles to settle unhindered [8].

Tables 3 and $\mathbf{4}$ summarize the complete comparison of gold distribution and ratio of concentration in concentrates 1 and 2, from the different minerals tested in this study.

\section{Conclusions}

Elutriation is not suitable for gravimetric concentration of precious metals if they are embedded in complex oxide or sulfide matrix.

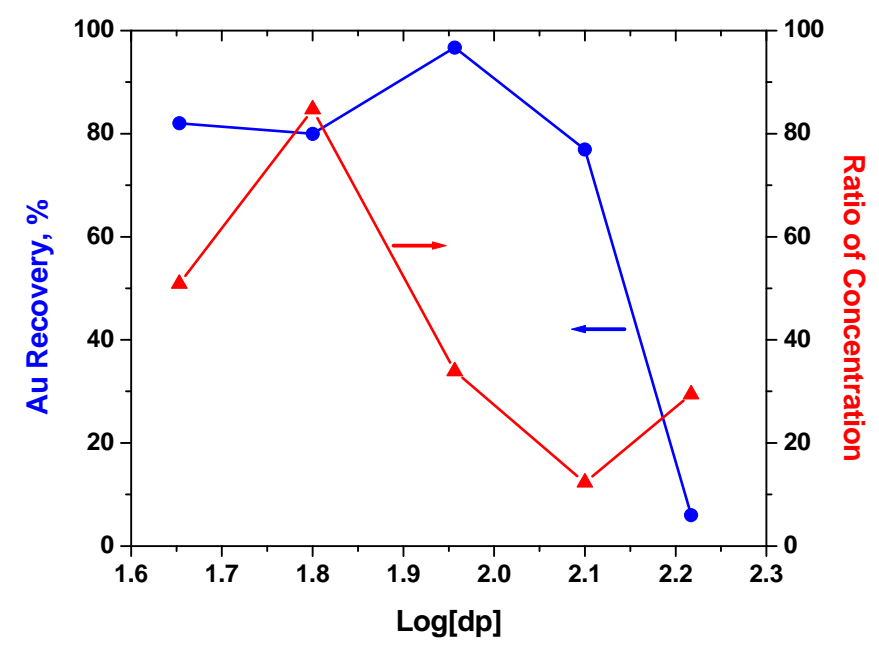

Figure 8. Gold recovery and ratio of concentration, as a function of a particle size, for concentrate 1 of black sand mineral.

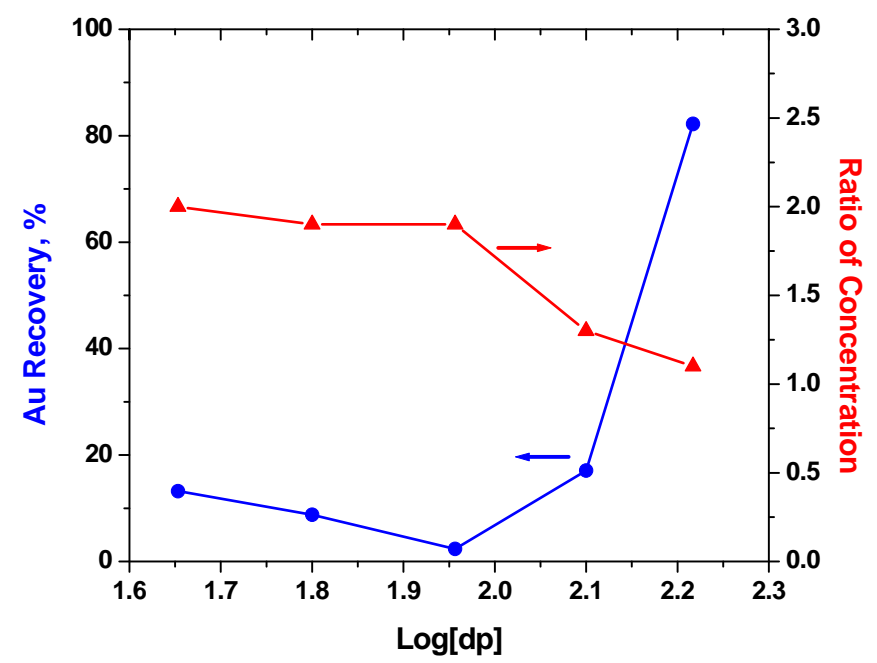

Figure 9. Gold recovery and ratio of concentration as a function of a particle size, for concentrate 2 of black sand mineral. 
Table 3. Gold recovery as a function of a particle size, from different minerals tested. (C-1): Concentrate 1, (C-2): Concentrate 2.

\begin{tabular}{|c|c|c|c|c|c|c|c|c|}
\hline \multirow[t]{2}{*}{$\begin{array}{c}\text { Average } \\
\text { Particle Size, } \\
{[\mathrm{dp}](\mu \mathrm{m})} \\
\end{array}$} & \multicolumn{2}{|c|}{$\begin{array}{c}\text { Gold Recovery } \\
\text { Oxide Mineral (\%) }\end{array}$} & \multicolumn{2}{|c|}{$\begin{array}{c}\text { Gold Recovery } \\
\text { Sulfide Mineral (\%) }\end{array}$} & \multicolumn{2}{|c|}{$\begin{array}{c}\text { Gold Recovery } \\
\text { Free Gold Mineral (\%) }\end{array}$} & \multicolumn{2}{|c|}{$\begin{array}{c}\text { Gold Recovery } \\
\text { Black Sand Mineral (\%) }\end{array}$} \\
\hline & C-1 & C-2 & C-1 & C-2 & C-1 & C-2 & C-1 & C-2 \\
\hline 302.5 & na & na & na & na & na & na & 6.0 & 82.22 \\
\hline 200 & na & na & na & na & na & na & 76.93 & 17.08 \\
\hline 165 & 74 & 22 & 7.5 & 60.21 & 73.9 & 22.4 & na & na \\
\hline 128 & 19 & 74.8 & 2.8 & 5.6 & 62.5 & 15 & 96.70 & 2.35 \\
\hline 90.5 & 1.46 & 89 & 1.0 & 11.81 & 19.6 & 42 & na & na \\
\hline 64 & - & 78.8 & 0.5 & 13.61 & 10.6 & 24.7 & na & na \\
\hline 49 & 1 & 92 & 5.6 & 21.16 & 2.8 & 24.9 & na & na \\
\hline 45 & 2.2 & 94.5 & - & - & na & na & 82 & 13.2 \\
\hline
\end{tabular}

na: not applicable.

Table 4. Ratio of concentration as a function of a particle size, from different minerals tested. (C-1): Concentrate 1, (C-2): Concentrate 2.

\begin{tabular}{|c|c|c|c|c|c|c|c|c|}
\hline \multirow[t]{2}{*}{$\begin{array}{c}\text { Average } \\
\text { Particle Size } \\
\text { [dp] }(\mu \mathrm{m})\end{array}$} & \multicolumn{2}{|c|}{$\begin{array}{l}\text { Ratio of Concentration } \\
\text { Oxide Mineral (\%) }\end{array}$} & \multicolumn{2}{|c|}{$\begin{array}{l}\text { Ratio of Concentration } \\
\text { Sulfide Mineral (\%) }\end{array}$} & \multicolumn{2}{|c|}{$\begin{array}{c}\text { Ratio of Concentration Free } \\
\text { Gold Mineral (\%) }\end{array}$} & \multicolumn{2}{|c|}{$\begin{array}{c}\text { Ratio of Concentration Black } \\
\text { Sand Mineral (\%) }\end{array}$} \\
\hline & C-1 & C-2 & C-1 & C-2 & C-1 & C-2 & C-1 & C-2 \\
\hline 302.5 & na & na & na & na & na & na & 29.4 & 1.1 \\
\hline 200 & na & na & na & na & na & na & 12.3 & 1.3 \\
\hline 165 & 5.5 & 1.24 & 30.2 & 2.79 & 18.9 & 2.2 & na & na \\
\hline 128 & 9.3 & 1.13 & 46.8 & 21.21 & 31.3 & 3.7 & 33.1 & 1.9 \\
\hline 90.5 & 157.5 & 1.01 & 158.2 & 9.02 & 42.7 & 4.9 & na & na \\
\hline 64 & - & 1.03 & 276.2 & 6.82 & 68.5 & 3.1 & na & na \\
\hline 49 & 127 & 1.02 & 36.4 & 2.70 & 54.3 & 6.1 & na & na \\
\hline 45 & 84 & 1.01 & - & - & na & na & 50.9 & 2.0 \\
\hline
\end{tabular}

na: not applicable.

cious metals if they are present in slimly and clayey black sands or as free gold.

For the free gold ores the best gold recoveries (70\%) and concentration ratios (70:1) were obtained for coarser particles sizes, from 90.5 to $165 \mu \mathrm{m}$.

For the black sands the best results $(96 \%$ of gold recovery) were for smaller sizes, i.e. 45 to $128 \mu \mathrm{m}$.

\section{REFERENCES}

[1] B. A. Wills, "Mineral Processing Technology," Pergamon Press, Oxford, England, 1979.

[2] M. G. Rasul, V. Rudolph and F. Y. Wang, "Particle Separation Using Fluidization Techniques," International Journal of Mineral Processing, Vol. 60, No. 3-4, 2000, pp. 163-179.

http://dx.doi.org/10.1016/S0301-7516(00)00016-8

[3] A. F. Taggart, "Handbook of Mineral Dressing," John Wiley \& Sons, New York, 1945.

[4] J. Elder, W. Kow, J. Domenico and D. Wyatt, "Gravity
Concentration-A Better Way," Proceedings of the International Heavy Minerals Conference, 18-19 June 2001, Australasian Institute of Mining and Metallurgy, pp. 115-118.

[5] E. G. Kelly and D. J. Spottiswood, "Introduction to Mineral Processing," John Wiley \& Sons, Inc., New York, 1992.

[6] A. Escamilla Ruvalcaba, "Tratamiento por Elutriación para la Concentración de Minerales de Oro y Plata," B.S. Thesis, Universidad de Sonora, Hermosillo, Sonora, 1999.

[7] J. M. Rodríguez, J. R. Sánchez, A. Alvaro, D. F. Florea and A. M. Estévez, "Fluidization and Elutriation of Iron Oxide Particles. A Study of Attrition and Agglomeration Processes in Fluidized Beds," Powder Technology, Vol. 111, No. 3, 2000, pp. 218-230. http://dx.doi.org/10.1016/S0032-5910(99)00292-2

[8] L. J. Cabri, "New Developments in Process Mineralogy of Platinum-bearing Ores," Proceedings of the Canadian Mineral Processors, 36th Annual Meeting, Ottawa, 2004, pp. 189-198. 